\title{
Rearing of Octopus vulgaris paralarvae: Present status, bottlenecks and trends is
}

\author{
J. Iglesias ${ }^{a, *, 1}$, F.J. Sánchez ${ }^{a}$, J.G.F. Bersano ${ }^{b}$, J.F. Carrasco ${ }^{c}$, J. Dhont ${ }^{\text {d }}$, \\ L. Fuentes $^{\text {a }}$, F. Linares ${ }^{\text {e }}$, J.L. Muñoz ${ }^{\text {f }}$, S. Okumura ${ }^{\text {g, }}{ }^{\text {, }}$, J. Roo ${ }^{\text {h }}$, \\ T. van der Meeren ${ }^{i}$, E.A.G. Vidal ${ }^{\mathrm{j}}$, R. Villanueva $^{\mathrm{k}}$ \\ ${ }^{\text {a }}$ Oceanographic Center of the Spanish Institute of Oceanography (IEO), Cabo Estai-Canido, Apartado 1.552, 36280 Vigo, Spain \\ ${ }^{\mathrm{b}}$ Departamento de Oceanografia, Fundação Universidade Federal do Rio Grande (FURG), CX. P. 474, Rio Grande, RS, 96.201-900, Brazil \\ ${ }^{\mathrm{c}}$ Fishery Research Center (CEP), Principado de Asturias, Avda. Príncipe de Asturias, s/n. 33212 Gijón, Spain \\ d Laboratory of Aquaculture and Artemia Reference Center, Department of Animal Production, Ghent University, Rozier 44, B-9000 Gent, Belgium \\ ${ }^{\text {e } C e n t e r ~ o f ~ M a r i n e ~ R e s e a r c h ~(C I M A), ~ X u n t a ~ d e ~ G a l i c i a, ~ P e d r a s ~ d e ~ C o r o ́ n, ~ s / n . ~} 36620$ Vilanova de Arousa, Pontevedra, Spain \\ ${ }^{\mathrm{f}}$ Instituto de Investigación y Formación Agraria y Pesquera (IFAPA), Junta de Andalucía, Apdo. 16, 11500 El Pto. de Sta. María, Spain \\ g Yashima Station (YS), National Center for Stock Enhancement, Fisheries Research Agency, Yashimahigashi Takamatsu Kagawa 761-0111, Japan \\ ${ }^{\mathrm{h}}$ Institute of Marine Science of Canary Islands (ICCM), Carretera de Taliarte s/n. 35200 Telde - Gran Canaria, Spain \\ ${ }^{\mathrm{i}}$ Institute of Marine Research, Austevoll Research Station, N-5392 Storebø, Norway \\ ${ }^{j}$ Centro de Estudos do Mar, Universidade Federal do Paraná (UFPR), Cx. Postal 50.002, Pontal do Paraná, PR. 83.255-000, Brazil \\ ${ }^{\mathrm{k}}$ Institut de Ciències del Mar, CSIC (ICM), Passeig Marítim de la Barceloneta 37-49, E-08003 Barcelona, Spain
}

Received 26 April 2006; received in revised form 5 February 2007; accepted 8 February 2007

\begin{abstract}
Due to the high mortality rates and poor growth generally observed in Octopus vulgaris paralarval rearing experiments, it was decided to organize a working group in order to formulate recommendations to tackle this problem. Over a dozen scientists representing the most active current research groups related to this subject attended the meeting in Vigo, Spain, in November 2005. The aim of this working group was to determine the bottlenecks that prevent success in paralarval rearing, define the most appropriate rearing conditions, and identify required future research.

This paper describes rearing techniques for the $O$. vulgaris paralarvae used by the different research participant teams, with regard to tank systems, feeding environment, and diets (Artemia, crustacean zoeae, sandeel flakes, copepods, etc.). Additionally, it includes other related themes such as the culture of Artemia and copepods, organisms that are commonly used in paralarval rearing.

When embarking on $O$. vulgaris rearing it is advised to use prey rich in DHA (docosaenoic acid, 22:6n-3) and EPA (eicosapentaenoic acid, 20:5n-3), and with high DHA/EPA ratio. Such prey could be enriched Artemia, accompanied or not by crustacean zoeae or any microdiet. It is also recommended that, in future studies, values of growth and survival rates are recorded at the beginning of the benthic phase, in order to compare them to successful previous studies. Dry weight and DHA/EPA ratio of paralarvae may also be good criteria to define paralarval viability and evaluate success of the rearing system.
\end{abstract}

\footnotetext{
Th This paper is dedicated to the memory of Dr Shigenobu Okumura, who passed away on August 21, 2006

* Corresponding author. Tel.: +34 986 492111; fax: +34 986498626.

E-mail address: jose.iglesias@vi.ieo.es (J. Iglesias).

${ }^{1}$ The order of authorship following the second author is alphabetical.

Deceased.
} 
It is further concluded that the nutritional aspect is the most important factor influencing larval mortality. Certain lipids (phospholipids, cholesterol, and polyunsaturated fatty acids), amino acids (lysine, leucine and arginine), and essential elements (e.g. copper) play a relevant role in the larval nutrition. It is believed that the PUFA content, especially DHA and EPA, constitutes one of the basic nutritional requirements.

Regarding new research lines, no standardized system for paralarval rearing exists, and it is essential to make progress on this issue. Research on nutritional requirements is considered an area of highest priority, especially the development of a specific enrichment for Artemia, the search for alternative live preys, and the development of suitable formulated diets.

(C) 2007 Elsevier B.V. All rights reserved.

Keywords: Octopus vulgaris; Cephalopoda; Paralarval rearing; Nutrition; Biochemistry

\section{Contents}

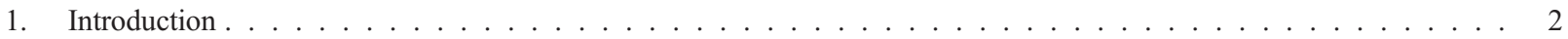

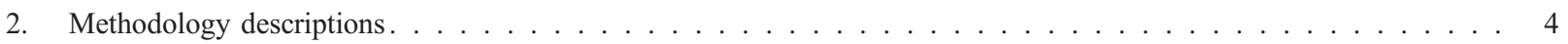

2.1. Paralarval rearing systems . . . . . . . . . . . . . . . . . . . . . . . . . . 4

2.1.1. Paralarval rearing using enriched Artemia and compound diets. R. Villanueva (CSIC, Barcelona) . . 4

2.1.2. Paralarvae rearing with Artemia and crustacean zoeae. 1. F.J. Sánchez (I.E.O., Vigo) . . . . . . . . . 5

2.1.3. Paralarvae rearing with Artemia and crustacean zoeae. 2. J.F. Carrasco. C.E.P. (Asturias) . . . . . . . 5

2.1.4. Paralarvae rearing with Artemia and crustacean zoeae. 3. J. Roo (I.C.C.M., Canary Islands) . . . . . 6

2.1.5. Paralarvae rearing using enriched Artemia and Ammodytes personatus. S. Okumura. Y.S. (Japan) . . 6

2.1.6. Paralarvae rearing using Artemia and copepods. E. A. G. Vidal. UFPR. (Brazil) . . . . . . . . . . . 6

2.2. Prey production methods . . . . . . . . . . . . . . . . . . . . 6

2.2.1. Intensive cultivation of the copepod $A$. tons a and its utilization in $O$. vulgaris larviculture.

J. G. F. Bersano FURG (Brazil) and E. A. G. Vidal. UFPR (Brazil) . . . . . . . . . . . . . . . . . 6

2.2.2. Copepods production and biochemical composition. T. van der Meeren. I.M.R. (Norway) . . . . . . 7

2.2.3. Use of ongrown Artemia. J. Dhont. Ghent University (Belgium) . . . . . . . . . . . . . . . . . . . 7

3. Comparison of broodstock handling and paralarval rearing techniques . . . . . . . . . . . . . . . 8

4. Recommendations. . . . . . . . . . . . . . . . . . . ......8

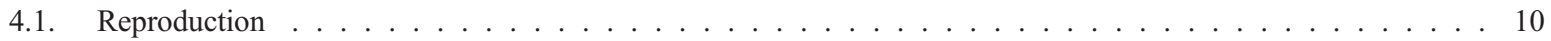

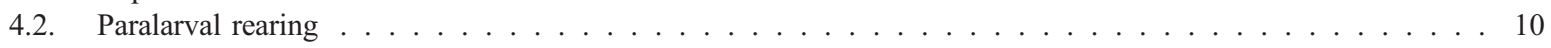

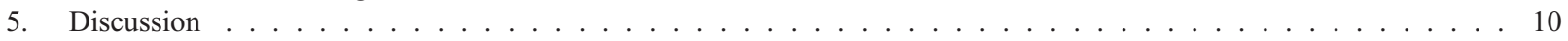

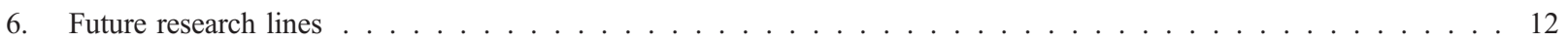

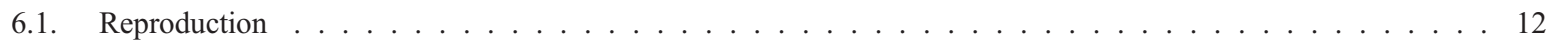

6.1.1. Control of the sexual maturation . . . . . . . . . . . . . . . . . . . . . . 12

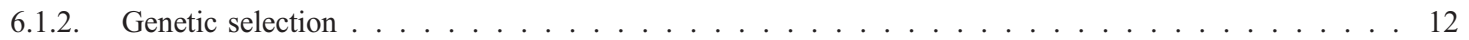

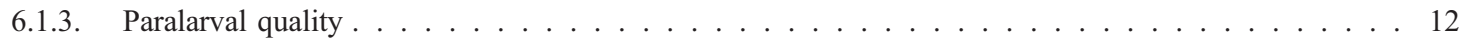

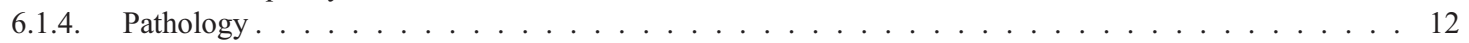

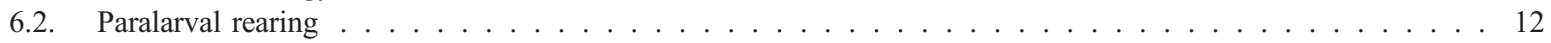

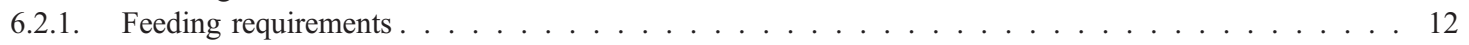

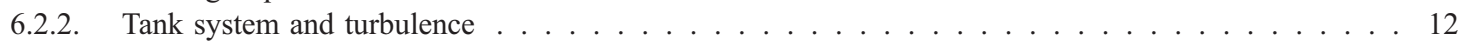

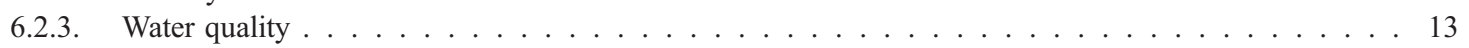

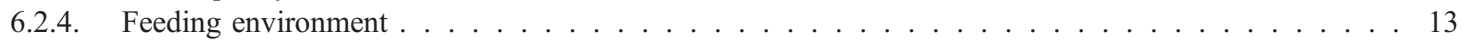

6.2.5. Paralarval behaviour . . . . . . . . . . . . . . . . . . . . . . . . . . . . . . . . . . . . . . . . . . . . . . . . . .

6.2.6. Paralarval development . . . . . . . . . . . . . . . . . . . . . 13

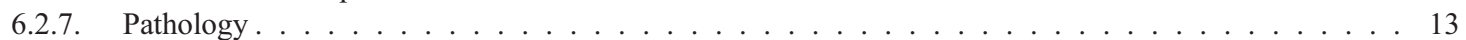

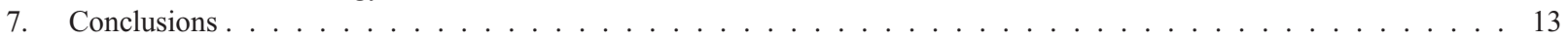

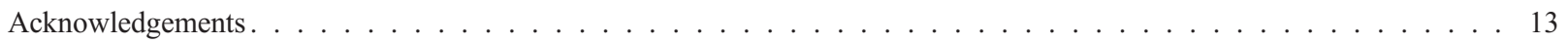

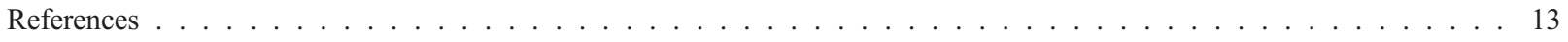

\section{Introduction}

Octopus vulgaris is one of the best-known and most studied cephalopods in the world. There are compre- hensive studies on its biology, physiology, behaviour, reproduction, growth, culture, etc. (see reviews by: Wells, 1978, 1990; Mangold, 1983; O’Dor and Wells, 1987; Portner et al., 1994; Hanlon and Messenger, 1996; 
Vaz-Pires et al., 2004). Therefore, this knowledge constituted an excellent starting point when this species was considered as a new candidate for aquaculture.

The main features of Octopus vulgaris subadults and adults that favour its potential for culture are: (1) high food conversion rate, incorporating $40-60 \%$ of the ingested food (Mangold and Boletzky, 1973; Wells, 1978; Mangold, 1983); (2) fast growth (around 3\% daily growth rate, Mangold and Boletzky, 1973), with males reaching the biggest size (Mangold, 1983; Forsythe and Van Heukelem, 1987); (3) high protein content, representing 70 to $90 \%$ dry weight of its body composition (O’Dor and Wells, 1987; Lee, 1994); (4) high fecundity, producing from 100 to 500 thousand eggs per female (Wells, 1978; Mangold, 1983; Iglesias et al., 1996, 1997).

Additional advantages are the social and economic relevance of this species, which is substantiated by its price and the size of its market in the Mediterranean, Latin America and Asia, while at the same time, landings by fishery are declining everywhere (Globefish, 2006). Hence, the culture of octopus from paralarvae to adults constitutes one of the most interesting new species for the aquaculture sector.

O. vulgaris 'paralarvae' (term defined by Young and Harman, 1988) hatch with about 1.0-1.5 mm of mantle length (ML) (ca. 1.5-2.9 mm total size) (Fig. 1). They are planktonic, swim actively and have high metabolic rates, requiring large quantities of live prey of adequate motility and nutritional quality (Villanueva, 1995; Parra et al., 2000; Iglesias et al., 2000; Navarro and Villanueva, 2000, 2003). During the planktonic phase, they undergo strong morphological changes mainly due to the fast growth of the arms relative to the mantle. As a result, the squid-like shape of hatchlings progressively merges to the octopus shape at settlement (Fig. 2). The duration of

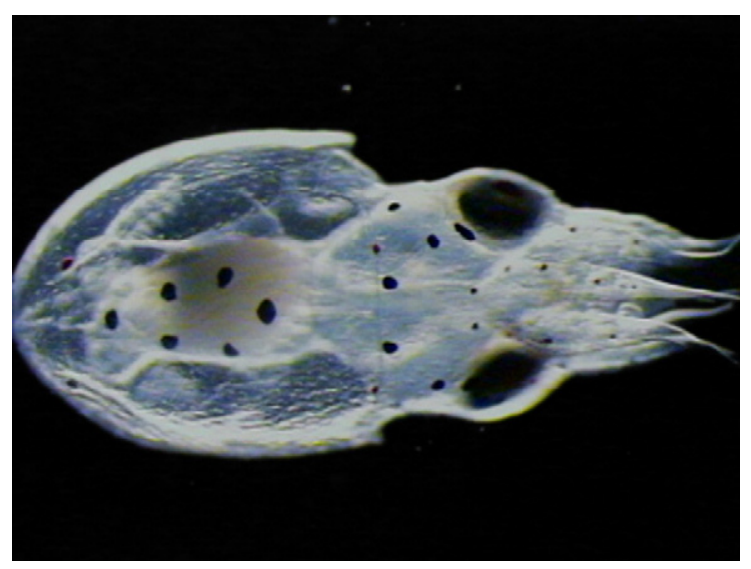

Fig. 1. 0 day-old $O$. vulgaris paralarva (1.5 mm DML, 3 suckers per arm).

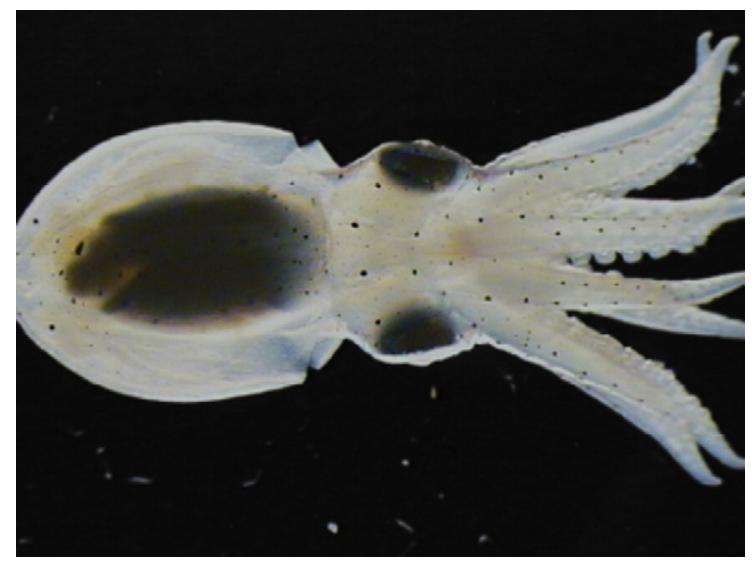

Fig. 2. 52 day-old $O$. vulgaris paralarva (5.75 mm DML, 21 suckers per arm).

the planktonic period is temperature-dependent and lasts around $47-54$ days at $21.2{ }^{\circ} \mathrm{C}$ and $30-35$ days at $23{ }^{\circ} \mathrm{C}$ (Imamura, 1990; Villanueva, 1995), after which the octopuses start settling to the bottom.

In Japan, Itami et al. (1963) were the pioneers in culturing this species and succeeded to rear the paralarvae using Palaemon serrifer zoeae as their main prey. They obtained benthic juveniles at 33 days maintaining a mean temperature of $24.7^{\circ} \mathrm{C}$ and reaching a survival rate of $5 \%$ at 60 days. Imamura (1990) reported on the main $O$. vulgaris paralarvae rearing experiments carried out in Japan attempting to obtain juveniles for enhancement programs in the 80 's. In one of these trials, survival values of $67.1 \%$ at day 22 were reached at mean temperatures of $25.1{ }^{\circ} \mathrm{C}$, using Artemia as the only prey. Hamazaki et al. (1991) attained 23,700 individuals (28.9\% of survival) at day 25 in a $20 \mathrm{~m}^{3}$ tank at mean temperature of $26.9{ }^{\circ} \mathrm{C}$, using only Artemia enriched with Nannochloropsis sp. as live prey for paralarvae diet. This clearly demonstrates the potential and feasibility of $O$. vulgaris mass production. Nowadays, research on $O$. vulgaris in Japan is basically focused on obtaining benthic juveniles for restocking programs (S. Okumura, personal communication).

It was also during the 90's that Spanish scientists initiated research on $O$. vulgaris aquaculture, focusing both on paralarval rearing and the ongrowing of subadult individuals captured from the wild. Villanueva (1994, 1995) and Villanueva et al. (1995, 1996), were able to obtain benthic juveniles of this species from the Atlantic-Mediterranean area with a survival of $9 \%$ and $0.8 \%$ at 60 days using various crustacean zoeae as a prey and maintaining a mean temperature of $21.2{ }^{\circ} \mathrm{C}$.

Moxica et al. (2002), using Artemia and Maja brachydactyla zoeae, achieved $8.3 \%$ of survival for 
one month old paralarvae. In 2001, using the same prey types, the complete life cycle of $O$. vulgaris was closed for the first time (Iglesias et al., 2004), with paralarval survival of $31.5 \%$ at day 40 and mean temperature of $22.5{ }^{\circ} \mathrm{C}$. Later, Carrasco et al. (2005) obtained similar results, utilizing the same live preys.

Despite the research effort taken until now, the rearing of $O$. vulgaris paralarvae is generally characterised by high mortality rates and poor growth, which hamper the entire culture of this species.

Due to the difficulty of producing benthic juveniles at a commercial scale, one alternative for the production of Octopus was assessed through ongrowing subadults in tanks on land and in cages at sea (Iglesias et al., 1996, 1997; Rama-Villar et al., 1997).

In the mid 90s, several private enterprises in Spain (particularly in Galicia) started trials on ongrowing of octopus in sea cages that were specifically developed for this purpose. The cages had submerged stacks of PVC tubes, which were used as shelters by the animals. In these experiments, wild-captured octopuses were grown for approximately four months until they reached commercial size (Rama-Villar et al., 1997; Rey-Méndez et al., 2003).

Several Spanish research institutes continued working with $O$. vulgaris, focusing their studies on the ongrowing phase (Sánchez et al., 1998; Giménez et al., 1999; García et al., 2001, 2003a,b; Otero et al., 2001; Tuñón et al., 2001; Aguado and García, 2002; García and Aguado, 2002; Cerezo and García, 2003; Muñoz, 2003; Rey-Méndez et al., 2003; Rodríguez et al., 2003, 2006; Oltra et al., 2005). Other studies related to breeding behaviour, spawning, and embryonic development of $O$. vulgaris in captivity were carried out by Moxica et al. (2001).

From 2001 to 2004, a Spanish national research plan (JACUMAR PULPO) was developed, focusing on paralarval rearing and ongrowing. The final conclusions of this project revealed that the main problem in the cultivation of this species was the high mortality rates and the poor paralarval growth. This was attributed mainly to the lack of standardized culture techniques and nutritional deficiencies in the diet of paralarvae, especially in $n-3$ highly unsaturated fatty acids (n-3 HUFA).

Therefore, it was decided that the problem of paralarval rearing needed specific attention, and a working group was organized to examine these bottlenecks. The working group comprised active researchers on this field, either specialised directly in paralarval rearing of $O$. vulgaris or in other relevant aspects that could contribute to resolve the problems (production of a suitable food for paralarvae, tank design and their implications, etc.). The specific objectives of the working group included: (1) to describe and discuss the different paralarval rearing systems used; (2) to evaluate the mortality causes during the first two months of life; and (3) to establish priorities in the research lines to be followed in the paralarval rearing process.

This document does not intend to be a comprehensive bibliographic revision of the current situation of research on $O$. vulgaris culture, as in fact there is a recent work on this subject (Vaz-Pires et al., 2004), but the objective is to make a review based on the data, discussions and conclusions that arose during the workshop.

\section{Methodology descriptions}

This section presents the different methodologies and the most relevant results obtained by each of the participating teams. All these groups work directly with paralarval rearing of $O$. vulgaris, or deal with related themes such as the culture of Artemia or copepods organisms commonly used in paralarval rearing.

\subsection{Paralarval rearing systems}

\subsubsection{Paralarval rearing using enriched Artemia and compound diets. $R$. Villanueva (CSIC, Barcelona)}

During the first experiments, zoeae from two crustacean species (Liocarcinus depurator and Pagurus prideaux), were used as live food (Villanueva, 1994, 1995; Villanueva et al., 1995, 1996). However, during recent years the aim of the research focus shifted to the use of artificial prey and the determination of the feeding requirements of the paralarvae using comparative analysis of the biochemical profiles of the reared octopus paralarvae, the wild juveniles and both natural and artificial prey, as well as enzymatic and digestive capabilities of the paralarvae. All experiments were carried out on a small-scale, using replicate tanks of 25-50 L and constant $24 \mathrm{~h}$ light. Larvae were fed enriched AF Artemia nauplii ( $450 \mu \mathrm{m}$ in length and densities of 2 to 10 , usually 4-6 nauplii $\mathrm{mL}^{-1}$ day $^{-1}$ ) (Villanueva et al., 2002, 2004), Artemia biomass supplemented with inert diets such as experimental pellets of $250-500 \mu \mathrm{m}$ (Navarro and Villanueva, 2000), millicapsules obtained by a gelification and coacervation process (Villanueva et al., 2002; Navarro and Villanueva, 2003), and amino acid solutions added directly to the rearing tank (Villanueva et al., 2004). All these experiments displayed low growth and low survival rates and were limited to the first month of culture, however, they offered an approach to the biochemical and nutritional requirements of the 
paralarvae. Navarro and Villanueva $(2000,2003)$ studied the lipid and fatty acid requirements of the paralarvae and natural preys used in successful cultures (crab zoeae, mysis) showing the relatively high requirements for polyunsaturated fatty acids (PUFA), phospholipids and cholesterol. Poor growth and high mortality in paralarval rearing using Artemia nauplii or Artemia biomass supplemented with dry or encapsulated microdiets is probably caused by a nutritional imbalance in the fatty acid profile (i.e. DHA/EPA ratio) produced by the artificial feeding. The amino acids, lysine, leucine and arginine represented half of the total essential amino acid content of the paralarvae and should be considered for the design of artificial diets. The paralarvae seem to be able to incorporate amino acids directly from the seawater and thereby increase their survival, but its effect on growth is unclear (Villanueva et al., 2004). Analyses of the elemental profiles showed the richness in copper of hatchling octopus, that may indicate a particular nutritional requirement for this element. Reared octopus paralarvae fed Artemia nauplii, a prey with relatively low copper content (20 times lower that $O$. vulgaris hatchlings and 8 times lower that $M$. brachydactyla zoeae), showed nearly half of the copper content compared to the "natural" profile in octopus hatchlings or wild juveniles, suggesting a dietary effect (Villanueva and Bustamante, 2006).

\subsubsection{Paralarvae rearing with Artemia and crustacean zoeae. 1. F.J. Sánchez (I.E.O., Vigo)}

In 2001, the closing of the completed life cycle of $O$. vulgaris from paralarvae to adult was achieved for the first time under culture conditions, using the following methodology: two thousand recently hatched (day 0 ) paralarvae were transferred to a $1 \mathrm{~m}^{3}$ PVC tank at a concentration of 2 ind $\mathrm{L}^{-1}$. The tank was circular $(130 \mathrm{~cm}$ in diameter) with black wall and white bottom. Mean water temperature was $22.5{ }^{\circ} \mathrm{C}$, and salinity $35 \mathrm{ppt}$. A $24 \mathrm{~h}$ light cycle was provided with two $36 \mathrm{~W}$ daylight fluorescent tubes, resulting in an intensity of 600-1000 lux at the water surface. Closed water recirculation with central aeration was maintained during the first week. Microalgae (Chlorella sp., Isochrysis galbana and Chaetoceros sp.) were added daily in order to feed the remaining preys in the culture tank, as to keep them in the best nutritional condition. From day 8 on, the water circulation was partially open $\left(10 \mathrm{~L} \mathrm{~min}^{-1}\right) 4 \mathrm{~h}$ per day. The tank bottom was cleaned by siphoning every 4 days. Live diet consisted of adult Artemia (1-4 mm total length) cultivated at $25{ }^{\circ} \mathrm{C}$ during a week with a commercial cereal mix, and enriched for $24 \mathrm{~h}$ with Chlorella sp. Artemia concen- tration was of $0.05-0.1$ ind $\mathrm{mL}^{-1}$. As a complementary diet, spider crab (M. brachydactyla) zoeae were added 4 days per week at a concentration of $0.01-0.1$ ind $\mathrm{mL}^{-1}$.

Mean dry weight of paralarvae at hatching was $0.34 \pm$ $0.01 \mathrm{mg}$. During the first week they actively consumed the adult Artemia supplied, but when spider crab zoeae were added as a complementary diet, paralarvae showed a clear preference for this prey. At day 40 , survival was $31.5 \%$, the paralarvae had 23 suckers per arm, and they started to migrate to the tank bottom, beginning the settlement process. Mean dry weight of paralarvae at day 45 was $9.5 \pm 1.9 \mathrm{mg}$. The good results obtained with the crab zoeae supply lead us to believe that it is essential to continue with the identification of the essential nutritional components of Maja zoeae in order to incorporate these in Artemia, and to find a feasible and practical method to use these zoeae. For additional information see Iglesias et al. (2002, 2004).

\subsubsection{Paralarvae rearing with Artemia and crustacean zoeae. 2. J.F. Carrasco. C.E.P. (Asturias)}

In 2002 Carrasco et al. $(2003,2005)$ succeeded in closing the life cycle of $O$. vulgaris under culture conditions. Although the preys used (Artemia, Maja zoeae) were similar to those used by Iglesias et al. (2004), the methodology differed considerably. For paralarval rearing, a recirculation system with a $150 \mathrm{~L}$ capacity was used. It consisted of three white parabolic polyester fibre tanks, with a diameter of $52 \mathrm{~cm}$, a height of $40 \mathrm{~cm}$ with a water distribution system fitted in the base of each tank, a $60 \mathrm{~L}$ reservoir, a centrifugal pump, and a biological filter. The seawater flow rate was maintained at about $0.7-1.0 \mathrm{~L}$ $\min ^{-1}$. Density was 25 paralarvae $\mathrm{L}^{-1}$. Mean water temperature was $21.2{ }^{\circ} \mathrm{C}$ and mean salinity $34.4 \mathrm{ppt}$. Rearing tanks were illuminated with light tubes for $12 \mathrm{~h}$ day $^{-1}$ in every trial. Paralarvae were fed twice daily with live, hatched zoeae of $M$. brachydactyla, maintaining a concentration of $0.7-1.0$ zoeae $\mathrm{mL}^{-1}$. Three times a week 7-10 day-old hatched Artemia enriched with the microalgae Tetraselmis suecica were supplied. Artemia concentration was $0.3-0.8$ individuals $\mathrm{mL}^{-1}$. Frozen shrimp were also supplied from day $40 \mathrm{on}$.

At hatching, paralarvae showed an approximate mantle length of $2.1 \mathrm{~mm}$, a dry weight of $0.3 \mathrm{mg}$, and three suckers on each arm. At day 20, survival was 59\% in one experiment and approximately $90 \%$ in the two others. After 60 days, 23 benthic individuals survived in one of the experiments, with a survival rate of $3.4 \%, 91.9 \pm$ $15.33 \mathrm{mg}$ mean wet weight, $22.02 \pm 3.8 \mathrm{mg}$ dry weight, and 27-30 suckers on each arm. These results were published by Carrasco et al. $(2003,2005,2006)$. 


\subsubsection{Paralarvae rearing with Artemia and crustacean zoeae. 3. J. Roo (I.C.C.M., Canary Islands)}

An experiment was carried out to study the nutritional effect of different food sources. Newly hatched octopus paralarvae were fed during the first months with three different live prey combinations: enriched Artemia metanauplii (56 h) (A1 Selco; INVE Aquaculture, Belgium), Grapsus grapsus zoeae supplemented with enriched Artemia, and Plagusia depressa zoeae supplemented with enriched Artemia. Treatments were carried out in triplicates using $100 \mathrm{~L}$ cylinderconical fibreglass tanks set with up-welling system for water circulation.

Survival rate was significantly improved with the use of both crab zoeae (11-27\% with G. grapsus; $7-10 \%$ with $P$. depressa at 28 days after hatching [dah]) in comparison to diet exclusively based on Artemia $(0-18.5 \%$ at 22 dah). Paralarvae dry weight was also higher in treatments using crabs zoeae $(1.14 \pm 0.49 \mathrm{mg}$ with $G$. grapsus; $1.12 \pm 0.22 \mathrm{mg}$ with $P$. depressa at 28 dah) than in those exclusively fed on Artemia $(0.78 \pm$ $0.02 \mathrm{mg}$ at $20 \mathrm{dah}$ ). Besides, some histological alterations on the digestive gland morphology were observed in paralarvae fed exclusively on Artemia. Biochemical composition of preys showed that the beneficial effect of the crabs zoeae supplementation could be related to a higher essential fatty acid (EFA) content, particularly arachidonic acid (ARA) content. Although it was showed that levels of n-3 HUFA, and mainly DHA in the zoeae, seem to be insufficient to meet paralarvae requirements. (Socorro et al., unpublished data).

\subsubsection{Paralarvae rearing using enriched Artemia and} Ammodytes personatus. S. Okumura. Y.S. (Japan)

Octopus paralarvae were reared during the first months being fed two types of Artemia (large and small), supplemented with frozen flakes of Pacific sandeel $(A$. personatus). Rectangular tanks of 500 and $4000 \mathrm{~L}$ were used, with constant illumination and water temperature kept at $25^{\circ} \mathrm{C}$. Survival, growth and HUFA composition were determined in paralarvae and food organisms.

Survival at day 32 was significantly higher with large Artemia (45.9\%) than with the smaller ones $(2.7 \%)$. Similarly, the mean wet weight was $37.3 \mathrm{mg}$ for the 32 day old paralarvae fed large Artemia, whilst $18.2 \mathrm{mg}$ fed smaller ones.

Supplementing sandeel flakes improved the DHA/ EPA ratio of paralarvae, since both types of Artemia contained only minimal DHA. DHA/EPA ratio in 32day-old paralarvae of both Artemia groups was equal (1.5), similar to that of hatchlings and wild subadults (Okumura et al., 2005).
2.1.6. Paralarvae rearing using Artemia and copepods. E. A. G. Vidal. UFPR. (Brazil)

Due to morphological and behavioural similarities between Loligo squid and Octopus paralarvae the rearing techniques developed for squid (Vidal et al., 2002, 2005) were applied to Octopus paralarvae with the aim of improving survival rates. In the case of Loligo, the tank hydrodynamics (small cylindrical tanks, $1.0 \mathrm{~m}$ diameter, $220 \mathrm{~L}$, and a circular current, 1.0 to $1.4 \mathrm{~cm} \mathrm{~s}^{-1}$ ) contributed to reduce skin and fin damage of paralarvae and thus, improved their survival.

Therefore $O$. vulgaris paralarvae were reared in a closed recirculation system including six replicate tanks of $100 \mathrm{~L}$ with attached filtration (see Vidal et al., 2002 for details) at $20 \pm 1{ }^{\circ} \mathrm{C}$ and fed a diet of enriched Artemia nauplii supplemented with copepods (Acartia tonsa), juvenile mysids (Metamysidopsis elongata atlantica) and crab zoeae (Callinectes sapidus). Food was supplied 4 times a day and prey densities maintained above 0.15 prey $\mathrm{mL}^{-1}$. Mean dry weight of paralarvae at hatching was $0.24 \pm 0.2 \mathrm{mg}$ and growth rates ranged from 4.1 to 4.8 dry weight day ${ }^{-1}$ at day 40 . Survival rates varied greatly from 1 to $39 \%$ at day 40 , and the best survival was obtained with the utilization of the copepod $A$. tonsa up to day 15 as a supplement to enriched Artemia.

It was observed that $O$. vulgaris paralarvae were being subject to mortality caused by damage in their arms and mantle. The damages were caused by constant friction against the tank walls and bottom. Initial damage in the arms was noticed from 5 to 10 day after hatching and the ventral arms were the most affected due to constant contact with the bottom of the tanks. The degree of damage was closely related to the small size of the tanks used and to the hydrodynamic behaviour and related circulation (circular current) inside the same. Therefore, different hydrodynamic configurations and directions were tested and the best results (i.e. small incidence of arms damage) were obtained with a gentle ascending fluid motion that reduced the contact of paralarvae with the tank and bottom walls. These results clearly show that tank design and fluid motion are key factors for paralarval survival, as it has been observed for fish (Rasmussen and McLean, 2004) and need further investigations.

\subsection{Prey production methods}

2.2.1. Intensive cultivation of the copepod A. tonsa and its utilization in O. vulgaris larviculture. J. G. F. Bersano FURG (Brazil) and E. A. G. Vidal. UFPR (Brazil)

Interest on the mass cultivation of copepods as an alternative live food for aquaculture has increased since the early 1990s, partly because of the global shortage of 
Artemia (Støttrup and McEvoy, 2003). Marine copepods have a higher nutritional value than rotifers and Artemia, (Watanabe et al., 1983; Sargent et al., 1997; Støttrup and Nosker, 1997), making them an attractive live food source to be used in the larviculture of fish larvae and invertebrates. Nevertheless, the use of copepods is still limited in aquaculture, due to the lack of a standard cultivation method and in most cases, the difficulty of getting large numbers of individuals in a short period of time. In the last years, an intensive method to culture copepods has been used in southern Brazil, with relative success (Bersano, 2003). It consists of a cylinder-conical 500 L black fibreglass tank, fitted with an airlift system and an egg collector that allows the collection of eggs every $24 \mathrm{~h}$.

This method was developed for the calanoid copepod A. tonsa, a planktonic free-spawning species, but other calanoid species can be also considered. The food used for the copepods consists of a mixed algal diet, made up of Thalassiosira fluviatilis and I. galbana. The stocking density is kept about 50 females $\mathrm{L}^{-1}$ and 30 males $\mathrm{L}^{-1}$ and checked every seven days. Tank production can be assessed every $24 \mathrm{~h}$ by eggs and nauplii counting. Maximum production is approximately $1.2-1.4$ million nauplii day $^{-1}$ per tank, with a mean production per culture volume about $1600-1800$ nauplii $\mathrm{L}^{-1}$ day $^{-1}$. Copepods produced with this method are currently being used in a series of experiments that include the paralarval rearing of $O$. vulgaris. In these experiments adult individuals of $A$. tonsa $(\sim 1 \mathrm{~mm})$ were used in a stocking density of around 80 copepods $\mathrm{L}^{-1}$ as a supplement to enriched Artemia nauplii during the first 15 days of $O$. vulgaris larviculture. The first results obtained are promising with survival rates from 20 to $38 \%$ at day 40 after hatching, and specific growth rates of around $4.6 \%$ dry weight day ${ }^{-1}$.

\subsubsection{Copepods production and biochemical composi-} tion. T. van der Meeren. I.M.R. (Norway)

Mesocosms (large enclosed bodies of water) can be manipulated to enhance zooplankton production (mainly copepods) (Naas et al., 1991). This has been regularly done in a $20,000 \mathrm{~m}^{3}$ seawater pond at IMR-Austevoll, Norway, between 1984 and 2001. The most important factors for managing the production are fertilisation to enhance primary production, mixing to prevent anoxic layers, and salinity control. A complete mesocosm draining is also needed to prevent the settlement of competing or predatory organisms on copepods. Copepods can be harvested by means of plankton filters (e.g. UNIK-900 wheel-filter) (van der Meeren, 1991; van der Meeren and Naas, 1997). There is a large production potential, and an average of $c a .80$ million copepods has been collected daily during a period of $4-5$ weeks at IMR-Austevoll.

Biochemical components of copepods from the mesocosm, including lipid classes, fatty acids of total lipid, free amino acids, total protein, protein-bound amino acids, pigments (astaxanthin and $\beta$-carotene), vitamins ( $\mathrm{A}, \mathrm{B}_{1}, \mathrm{~B}_{2}, \mathrm{C}, \mathrm{D}_{3}$ and $\left.\mathrm{E}\right)$, have been analysed from April to December over two years (van der Meeren et al., 2001; van der Meeren, 2003). Copepod size, dry matter content, and fraction of ash were also determined. Results show that copepods were surprisingly stable regarding several nutritional components. Copepods may be characterised by moderate lipid levels (10-15\% dry weight), dominated by polar lipids (approximately $60 \%$ total lipid). Three fatty acids were most abundant in total lipid, 16:0 (ca. 15\%), EPA (ca. 15\%), and DHA (ca. 30\%). ARA fraction was very low (less than 1\%), which gives an EPA/ARA ratio of about 24, while the DHA/EPA ratio was around 2 . The free amino acids fraction (FAA) was between 5 and $8 \%$ copepod dry weight, and a correlation between the FAA amount and salinity was found. FAA were dominated by glycine, arginine and taurine based on concentration. On average, 19 and $24 \%$ of FAA concentration were essential FAA. Protein determined from protein-bound amino acids (PAA) was 41 and $44 \%$ of copepod dry weight. Essential amino acids fraction in PAA was approximately $40 \%$ of amino acid concentration. Glycine, glutamine/glutamic acid, alanine, asparagine/ aspartic acid, and leucine were the most abundant PAA. Copepods were very abundant in astaxanthin (600-700 $\mu \mathrm{g} / \mathrm{g}$ dry weight), while $\beta$-carotene was not found. High concentrations of vitamin C (400-500 $\mu \mathrm{g} / \mathrm{g}$ dry weight) and vitamin $\mathrm{E}$ ( $\mathrm{ca} .110 \mu \mathrm{g} / \mathrm{g}$ dry weight) were found, while vitamin $\mathrm{A}$ and $\mathrm{D}_{3}$ occurred in trace amounts or were not detected.

Despite that nutritional requirements for octopus paralarvae are not yet completely defined, mass production of copepods in mesocosm may provide a transitional method for obtaining sufficient paralarval feed of reasonable nutritional quality, both for future research and for commercial exploration of methodology.

\subsubsection{Use of ongrown Artemia. J. Dhont. Ghent University (Belgium)}

Artemia is the most commonly used live food organism in commercial aquaculture but the vast majority uses freshly hatched nauplii or additionally enriched nauplii of $24 \mathrm{~h}$ old. However, in particular cases the use of larger Artemia is beneficial due to size and nutritional differences. Iglesias et al. (2006) affirm 
that $O$. vulgaris paralarvae prefer adult Artemia to nauplii. Offering larger prey leads to a higher food intake per hunting effort, substantial saving of cysts and reduction of costs. The nutritional value of adult Artemia is determined by the phytoplankton species or other food sources used during its culture, and eventually the nutritional quality of Artemia can easily be improved via enrichment products once the desired size is reached.

The intensive culture of Artemia requires appropriate culture water, an Artemia strain that is easily available, consistent in quality and has proper growth characteristics, and a suitable diet. A suitable diet includes live algae, dry algae, yeasts and ground agriculture byproducts (soy pellets, rice bran, wheat, etc.). The drastic impact of the fortuitous microflora is responsible for huge variations in the culture success when using yeasts or powdered feeds; a proper recirculation infrastructure is also needed to preserve the water quality.

Cultures can be run in a stagnant system, with open or closed flow through (and every intermediate) (Dhont and Lavens, 1996). Stagnant (=batch) systems require a simple infrastructure and daily maintenance, but water quality quickly deteriorates and does not allow for cultures of more than one week at moderate animal densities (about 5000 animals $\mathrm{L}^{-1}$ ). For longer cultures some kind of water treatment becomes necessary. Treatment may consist of a physical treatment to remove particles that are too big for Artemia to ingest (sedimentation tank, plate separator, protein skimmer, etc.) and/or a biological treatment to maintain nitrogen compounds and bacterial populations below acceptable levels (rotating biodisc, sandfilter, trickling filter, etc.). Culture results can be diverse, but using phytoplankton it is possible to get Artemia with a size of $2 \mathrm{~mm}$ in 4 days, $4 \mathrm{~mm}$ in a week and up to $8 \mathrm{~mm}$ in two weeks with a survival not lower than $70 \%$. More detailed information can be found in Dhont et al. (1991) and Dhont and van Stappen (2003).

\section{Comparison of broodstock handling and paralarval rearing techniques}

Once the various currently used paralarval culture systems and their culture performance were presented, a comparison was made, including reproduction with the aim to unify parameters, standardize the existing methodology and prepare recommendations. This information is shown in Tables 1 and 2. The most marked differences in relation to broodstock handling (Table 1) were male:female ratio, which is not a very determining factor, and the wide range of temperatures utilized (14$25^{\circ} \mathrm{C}$ ). Capture methods, transport conditions, food used and light were similar.

Table 2 shows that the biggest differences among the paralarvae rearing methods were tank volume, water system, light intensity and photoperiod, temperature and paralarvae and prey density. In contrast, common aspects concerning tank shape, aeration, and the use of crustacean zoeae and enriched Artemia were reported.

\section{Recommendations}

Based on the description of the various methods used for octopus rearing, and on ensuing discussion in the working group, a series of recommendations that could be useful for those researchers that take their first steps in the

Table 1

Summary of $O$. vulgaris broodstock capture methodology, transport and maintenance used by the different research groups

\begin{tabular}{|c|c|c|c|c|c|c|c|}
\hline & Barcelona & Vigo & Canary Island & Asturias & Andalusia & Brazil & Japan \\
\hline & ICM-CSIC & IEO & ICCM & CEP & IFAPA & FURG & YS \\
\hline Capture method & Traps & Traps & Traps & Traps & Traps and hooks & Pots and diving & $\begin{array}{l}\text { Pots, hooks } \\
\text { and lines }\end{array}$ \\
\hline Transport & $\begin{array}{l}\text { Oxygen supply } \\
\text { Low density }\end{array}$ & $\begin{array}{l}\text { Oxygen supply } \\
\text { Low density }\end{array}$ & Oxygen supply & $\begin{array}{l}<15 \text { min no water } \\
>15 \text { min aeration }\end{array}$ & Aeration & $\begin{array}{l}\text { Oxygen supply, } \\
\text { aeration }\end{array}$ & Oxygen supply \\
\hline $\begin{array}{l}\text { Sex ratio } \\
\quad \text { (male:female) }\end{array}$ & $1: 5-8$ & $1: 2$ & $1: 3$ & $1: 2-3$ & $1: 1$ & $1: 2-3$ & No males \\
\hline \multirow[t]{2}{*}{ Food } & Crab, fish & Crab, fish, mussel & Crab, fish & Crab, fish & Crab, fish & Crab, fish & $\begin{array}{l}\text { Crab, mantis } \\
\text { shrimp, fish }\end{array}$ \\
\hline & $\begin{array}{l}\text { Reduce to induce } \\
\text { spawning }\end{array}$ & $\begin{array}{l}\text { Reduce to induce } \\
\text { spawning }\end{array}$ & & & & & \\
\hline $\begin{array}{l}\text { Temperature } \\
\left({ }^{\circ} \mathrm{C}\right)\end{array}$ & $14-23$ & $15-20$ & $18-22$ & $15-20$ & $15-22$ & $19-23$ & $15-25$ \\
\hline Light & Darkness & Dim & Shaded & Dim & Shaded & Dim & $\begin{array}{l}\text { Shaded } \\
\text { ( } 90 \% \text { reduction) }\end{array}$ \\
\hline
\end{tabular}


Table 2

Summary of paralarval rearing conditions of $O$. vulgaris carried out by different research groups

\begin{tabular}{|c|c|c|c|c|c|c|c|}
\hline Parameters & $\begin{array}{l}\text { Barcelona } \\
\text { ICM-CSIC }\end{array}$ & Vigo IEO & $\begin{array}{l}\text { Canary } \\
\text { Islands } \\
\text { ICCM }\end{array}$ & Asturias CEP & $\begin{array}{l}\text { Andalusia } \\
\text { IFAPA }\end{array}$ & $\begin{array}{l}\text { Brazil } \\
\text { FURG }\end{array}$ & Japan YS \\
\hline Tank volume (L) & $25-50$ & 1000 & 100 & 30 & 400 & 100 & 500 \\
\hline Tank colour & Black & Black & Grey & White & Black, grey & Black & Orange \\
\hline Tank shape & Cylindrical and parabolic & Cylindrical & Cylindrical & Parabolic & $\begin{array}{l}\text { Cylindrical and } \\
\text { rectangular }\end{array}$ & Cylindrical & Cylindrical \\
\hline Water system & Open & $\begin{array}{l}\text { 1st week stagnant, } \\
\text { 2nd semi-open } \\
(3-4 h=100 \%)\end{array}$ & Open $25 \%$ day $^{-1}$ & $\begin{array}{l}\text { Open } \\
\text { (recirculation) }\end{array}$ & Open & $\begin{array}{l}\text { Closed } \\
\text { (recirculation) }\end{array}$ & $\begin{array}{l}5 \text { first days stagnant } \\
\text { then open system }\end{array}$ \\
\hline Aeration & No & Yes, intermediate & Yes, gentle & $\begin{array}{l}\text { Yes, gentle } \\
\text { (cleaning) }\end{array}$ & Yes, gentle & No & Yes, gentle \\
\hline Light & $\begin{array}{l}24 \mathrm{~h} \text { bulb } 60 \mathrm{w} 900 \mathrm{~lx} \text { at } 1 \mathrm{~cm} \\
\text { under the water surface }\end{array}$ & $\begin{array}{l}24 \mathrm{~h} \text { fluorescent (2) } \\
36 \mathrm{~W} 2000 \mathrm{~lx}\end{array}$ & Natural photoperiod & $\begin{array}{l}12 \mathrm{~h} \text { light-12 h } \\
\text { darkness; } \\
\text { fluorescent (1) } \\
40 \mathrm{~W}\end{array}$ & Natural photoperiod & $\begin{array}{l}10 \mathrm{~h} \text { light-14 h } \\
\text { darkness; } \\
\text { natural+cold } \\
\text { light }\end{array}$ & Fluorescent (1) $36 \mathrm{~W}$ \\
\hline Temperature & $19-23$ & $20-22$ & $21.5-22.5$ & $20-22$ & $19-22$ & $19-24$ & 25 \\
\hline Clear/green water & Clear & $\begin{array}{l}\text { Green Isochrysis }+ \\
\text { Nannochloropsis }\end{array}$ & Clear & Clear & $\begin{array}{l}\text { Green } \\
\text { Tetraselmis + Isochrysis }\end{array}$ & Clear & $\begin{array}{l}\text { Freshwater } \\
\text { Chlorella }\end{array}$ \\
\hline $\begin{array}{l}\text { Paralarvae density } \\
\text { (ind. } \mathrm{L}^{-1} \text { ) }\end{array}$ & $13-48$ & 5 & 25 & 25 & 20 & $5-30$ & 3 \\
\hline $\begin{array}{l}\text { Type and prey } \\
\text { density } \\
\text { (ind. } \mathrm{mL}^{-1} \text { ) }\end{array}$ & $\begin{array}{l}\text { Zoeae Liocarcinus and } \\
\text { Pagurus) nauplii Artemia } \\
\text { (2-6) and Artemia biomass }\end{array}$ & $\begin{array}{l}\text { Zoeae Maja }(0.01-0.1) \\
\text { (when available)+ } \\
\text { Artemia }(0.05-0.1)\end{array}$ & $\begin{array}{l}\text { Zoeae Grapsus }\left(15 \text { ind. } \mathrm{L}^{-1}\right)+ \\
\text { Artemia }(72 \mathrm{~h})(2)\end{array}$ & $\begin{array}{l}\text { Zoeae Maja } \\
(0.7-1)+\text { Artemia } \\
(3 \text { times/week }) \\
(0.5-0.7)\end{array}$ & $\begin{array}{l}\text { Zoeae }(\text { Carcinus }, \\
\text { Palaemon } \text { and Maja }) \\
(<0.1)+\text { Artemia }+ \text { Moina } \\
(4-5 \text { day-old })(1.0)\end{array}$ & $\begin{array}{l}\text { Crustacean zoeae, } \\
\text { copepods, mysids, } \\
\text { nauplii and adult } \\
\text { Artemia } 0.15-0.3 \\
\text { (4-5 takes) }\end{array}$ & $\begin{array}{l}\text { Artemia nauplii }+ \text { fish } \\
\text { flakes from } 5 \text { th day }\end{array}$ \\
\hline Size of prey & $\begin{array}{l}\text { Zoeae }(1.3-3.1 \mathrm{~mm} \mathrm{TL}) \\
\text { Artemia } \text { nauplii to } 1-3 \mathrm{~mm} \\
\text { Artemia biomass }\end{array}$ & $\begin{array}{l}\text { Zoeae: } 1 \mathrm{~mm} \mathrm{TL} \\
\text { Artemia: } 2-3 \mathrm{~mm} \text { TL }\end{array}$ & $\begin{array}{l}\text { Zoeae: } 1.5 \mathrm{~mm} \mathrm{TL} \\
\text { Artemia: } 0.85 \mathrm{~mm} \mathrm{TL}\end{array}$ & $\begin{array}{l}\text { Zoeae: } 1 \mathrm{~mm} \text { TL } \\
\text { Artemia retained } \\
\text { in } 300 \mu \mathrm{m} \text { sieve }\end{array}$ & $\begin{array}{l}\text { Zoeae: } 0.8-1.0 \mathrm{~mm} \\
\text { Moina: } 1.0-1.2 \mathrm{~mm} \\
\text { Artemia: } 1-3 \mathrm{~mm}\end{array}$ & $0.4-8 \mathrm{~mm}$ & $\begin{array}{l}650 \mu \mathrm{m} \text { (Artemia) } \\
1-2 \mathrm{~cm} \text { diameter, } \\
0.5-1 \mathrm{~mm} \text { thickness (FF) }\end{array}$ \\
\hline $\begin{array}{l}\text { Artemia } \\
\quad \text { enrichment }\end{array}$ & DCSuperSelco, Metionine & $\begin{array}{l}\text { Reared in commercial } \\
\text { cereal flour, enriched } \\
\text { with Nannochloropsis } \\
\left(5.10^{6} \text { cell } \mathrm{mL}^{-1}\right)\end{array}$ & $\begin{array}{l}\text { Artemia } \\
\text { enrichment } \\
\left(\mathrm{A}_{1} \text { Selco Inve }\right)\end{array}$ & $\begin{array}{l}\text { Reared and enriched } \\
\text { with Tetraselmis }\end{array}$ & $\begin{array}{l}\text { Reared and enriched with } \\
\text { Tetraselmis + Isochrysis } \\
\text { SuperSelco, Prolon }\end{array}$ & $\begin{array}{l}\text { Super SELCO and DHA } \\
\text { SELCO Inve }\end{array}$ & $\begin{array}{l}\text { Fish egg powder } \\
\text { (Plus Aquaran, } \\
\text { BASF Japan) }\end{array}$ \\
\hline Sampling & Every $7-10$ days & Every 7 days & Every 7 days & Every 10 days & Every $7-10$ days & $\begin{array}{l}\text { Daily up to day } 7 \\
\text { and every } 5 \text { days } \\
\text { thereafter }\end{array}$ & Every 5 days \\
\hline Survival & $\begin{array}{l}0.8 \% \text { at day } 60 \text { with zoeae, and } \\
54 \% \text { at day } 20 \text { with Artemia } \\
\text { nauplii (with poor growth) }\end{array}$ & $31.5 \%$ at day 40 & $11-27 \%$ at day 30 & $\begin{array}{l}89.6-93.5 \% \text { at } \\
\text { day } 20 \text { and } 3.4 \% \\
\text { at day } 60\end{array}$ & $5-15 \%$ at day 35 & $\begin{array}{l}1-20 \% \text { at day } 40 \\
\text { with Artemia and } \\
\text { from } 20-39 \% \text { at } \\
\text { day } 40 \text { with Artemia } \\
\text { and copepods }\end{array}$ & $10-30 \%$ at day 30 \\
\hline Cleaning & $\begin{array}{l}\text { Daily tank bottom } \\
\text { siphoning }\end{array}$ & $\begin{array}{l}\text { No bottom cleaning } \\
\text { until day } 30\end{array}$ & No bottom cleaning & $\begin{array}{l}\text { Every } 20 \text { days } \\
\text { changing tank by } \\
\text { pipetting and } \\
\text { checking the } \\
\text { survival }\end{array}$ & $\begin{array}{l}\text { Daily tank } \\
\text { bottom siphoning }\end{array}$ & $\begin{array}{l}\text { Bottom siphoning } \\
\text { daily or every other } \\
\text { day }\end{array}$ & $\begin{array}{l}\text { Daily tank bottom } \\
\text { siphoning after } \\
\text { 5th day }\end{array}$ \\
\hline
\end{tabular}


study of paralarval rearing of $O$. vulgaris was prepared. These recommendations are summarised in the following sections.

\subsection{Reproduction}

Nowadays, each laboratory successfully obtains eggs and viable hatchlings in sufficient amounts to develop paralarval rearing trials. Nevertheless, it is possible to give some specific recommendations to improve and standardize methods to obtain paralarvae for rearing:

To collect subadult and adult individuals from the wild, the use of basket traps is strongly recommended in order to avoid damage during captures of broodstock individuals. In addition, this gear is very selective and reduces fishery impact on the environment.

Mortality of adults during transport can be prevented through aeration, in the case of low densities, or through an oxygen supply for high densities. The use of individual PVC pipes or net bags could also reduce mortality.

In order to enhance the biochemical composition of paralarvae, it is recommended to include at least $30 \%$ of crustaceans in the broodstock diet. Low commercial value crustaceans and fish are specifically suitable.

If individuals are captured during the spawning season, it is sufficient to obtain mated females ( $>1 \mathrm{~kg}$ ), otherwise, during the rest of the year, males and females can be kept at a ratio of 1:3, respectively.

To avoid disturbance among individuals, spawning females and their respective egg masses may be transferred to separate tanks from the broodstock.

Handling and transport of breeding females and/or egg masses should be done before the second embryonic inversion to prevent premature hatching. Furthermore, sudden changes in the physical environment (e.g. temperature, salinity, $\mathrm{pH}$, light intensity), as well as mechanical stimuli, should be avoided as much as possible.

Care must be taken when collecting and transferring hatchlings in order to avoid stress and damages. Their skin is extremely delicate and can be easily damaged. Sampling after hatching must be carried out gently, either through individual counting or volumetric estimation.

\subsection{Paralarval rearing}

Due to the lack of knowledge on the basic biological, nutritional, physical, and behavioural requirements of octopus paralarvae, considerable and widely different efforts have been made to explore the feasibility of rearing these molluscs. Therefore, a wide variety of tank forms and colours, light conditions, as well as water supply, quality and turbidity has been tested. Further- more, a number of prey types and sizes have been applied, often under different feeding regimens (concentrations, feeding times, and food treatments). As a result, no standardized methods exist at the present for paralarval rearing. However, information provided in Table 2 by the working group leads to the following recommendations:

In case small volume tanks are used for the paralarval rearing trials, a water circulation system that avoids skin damages in paralarvae, especially in the arms, will be required.

When using larger tanks (more than $500 \mathrm{~L}$ ) an appropriate distribution of paralarvae and their preys in the water column should be sought. This can be achieved through the circulation system (water intake and outlet) or by gentle aeration.

Enriched Artemia are recommended as live prey due to its easy manipulation and availability, together with copepods, crustaceans zoeae or a suitable microdiet.

Regarding the lipid composition of reared paralarvae and that of their natural food, it can be deduced that they require a food source rich in polyunsaturated fatty acids (PUFA), phospholipids and cholesterol, and a moderate content in neutral lipids. Any diet used (Artemia enriched by any method, a microdiet or any live prey) should also present a high DHA/EPA index.

Additionally, any experiment on rearing paralarvae should provide data on growth in dry weight and survival rate when the benthic phase is reached (approximately 2 months of age at $21^{\circ} \mathrm{C}$ ). The values published in this review on the successful experiences that used Artemia as a prey supplemented with crustaceans zoeae can be used as a reference.

DHA/EPA ratio and dry weight of the paralarvae, related to temperature at a certain age, could be good criteria to define the paralarval viability and to evaluate the success of the rearing system.

\section{Discussion}

Acclimatisation of breeders in captivity does not pose any problem in octopus culture. The main recommendations to be taken into account to achieve good acclimatisation and spawning have been quoted above. Some authors put males and females together (Iglesias et al., 2000; Roo, personal communication), and others separate individually fertilised females caught at sea (Villanueva, 1995; Okumura et al., 2005). Most females mature and spawn in captivity, and a high hatching rate is frequently obtained.

One of the key issues that was discussed by the working group was the cause for the high mortality recorded during the planktonic phase of the octopus life 
cycle. Two possible factors initially mentioned were the lack of a standardised paralarval rearing system, and the absence of an appropriate food supply that meets the nutritional requirements of paralarvae. It became evident that even using two different culture systems (tank volume, colour, preys and paralarvae density, water flow, etc.) similar growth and survival results were obtained after supplying the same type of diet (Artemia and Maja zoeae) (Iglesias et al., 2004; Carrasco et al., 2005). This points out to nutrition as a key factor in octopus paralarval rearing success.

It is generally agreed that Artemia, specifically the franciscana strain, constitutes an attractive and wellaccepted prey for octopus paralarvae. Nevertheless, there is much discussion about the ideal size that should be used. Some authors (Vidal et al., 2002; Navarro and Villanueva, 2003) use Artemia nauplii (approximately $450 \mu \mathrm{m}$ and $750 \mu \mathrm{m}$ after enrichment) during the first weeks of culture, due to the easy production and lipid enrichment of this prey. Other authors (Moxica et al., 2002; Iglesias et al., 2004; Carrasco et al., 2005) used Artemia of ca. $2 \mathrm{~mm}$ of total length even in the beginning of the rearing process, and they consider that this size of prey could be suitable until the first month of culture; the results attained by Hamazaki et al. (1991), who used $A r$ temia $(1.5-2 \mathrm{~mm})$ enriched with Nannochloropsis sp., support this trend since they obtain survival of $28.9 \%$ on day 25 (until the onset of the benthic phase).

From the first month onwards, paralarvae need a prey larger than Artemia or crustacean zoeae. Although experiments with large prey like the mysid $M$. elongata atlantica (E. A. G. Vidal, unpublished data) and the amphipod Talitrus saltator have been carried out (Carrasco et al., 2003), the results are not conclusive yet.

Even though Artemia is well accepted and produces positive results until one month after hatching (especially if it is enriched), Artemia per se shows a biochemical composition that does not meet the nutritional requirements of octopus paralarvae, lacking long chain PUFA, essential for marine animals, like EPA which may be present in low amounts or absent in the lipid of the brine shrimp, and DHA which is basically absent (Navarro et al., 1992, 1993). This fact was also demonstrated in experiments carried out exclusively using enriched Artemia as live diet for paralarvae, where very low growth and survival indexes were recorded (Iglesias et al., 1997; Villanueva et al., 2002). The biochemical composition of the produced paralarvae is notably different than that of paralarvae reared with crustaceans zoeae namely by its lipid content that is especially lower PUFA (Navarro and Villanueva, 2000; Moxica et al., 2002). The only experiments using $A r$ - temia as the single diet and producing high paralarval survival during the first month after hatching, have been those experiments utilizing the microalgae Nannochloropsis sp. as enrichment for Artemia (Hamazaki et al., 1991; Moxica et al., 2006). Okumura et al. (2005) also attained good survival results at the end of the planktonic phase using Artemia and sandeel flakes, pointing out the importance of the DHA.

The first experiment using the copepod $A$. tonsa in combination with enriched Artemia (Vidal, methodological descriptions section) showed encouraging results when compared to a single diet of Artemia. This was probably related to the high nutritional quality of copepods, naturally rich in essential highly unsaturated fatty acids (HUFA), phospholipids and natural antioxidants (Sargent et al., 1997).

Several other research groups have reached the benthic phase (Itami et al., 1963; Villanueva, 1995; Iglesias et al., 2002, 2004; Carrasco et al., 2003, 2005) with very different culture conditions and systems. They had in common the use of live shrimp or crab zoeae $(P$. serrifer, M. brachydactyla, and P. prideaux) alone, or as a complement food together with Artemia. The biochemical composition of these crustaceans is characterised by a high phospholipid content, lack of triglycerides and high percentage of PUFA (n-3), specifically DHA (Navarro and Villanueva, 2000) which may be very important during early development due the high demand for membrane synthesis in rapidly growing larvae (Henderson and Sargent, 1985). These characteristics seem to explain the lipid requirements of octopus, and suggest shrimp and crab zoeas to be very valuable during the first period of paralarval feeding on live feed. Consequently, a diet made up of enriched Artemia and shrimps or selected crabs zoeae is currently the most appropriate to achieve better survival and growth indexes to reach the benthic phase.

This methodology enabled the completion of the octopus life cycle under culture conditions, and yielded juveniles that reached the adult stage and spawned in captivity (Iglesias et al., 2004; Carrasco et al., 2005). Nevertheless, this method cannot be applied on a commercial scale, as the availability of live zoeae is limited and its culture difficult to scale up to commercial levels. For these reasons it is considered essential to continue the search for a live prey or an Artemia enrichment that covers more efficiently the basic nutritional requirements of paralarvae.

In fact, much progress has been achieved in this regard. The importance of DHA and EPA fatty acids in paralarval diet has been evidenced. Protein and lipid biochemical profiles of paralarvae and their preys - 
highly important to determine this species' nutritional requirements during its planktonic phase (Navarro and Villanueva, 2000, 2003) - have been achieved. Future studies based on joint feeding (Artemia and microdiets) should consider a feed balanced in phospholipids, cholesterol and polyunsaturated fatty acids (specially DHA), with proteins rich in lysine, leucine and arginine (Navarro and Villanueva, 2000, 2003; Villanueva et al., 2002, 2004), and rich in essential elements as copper (Villanueva and Bustamante, 2006). Obtaining a balanced microdiet with an appropriate palatability and acceptance by the paralarvae is also an important objective to be reached.

Further investigation is needed on the reasons of the high acceptability of crab zoeae by octopus paralarvae and the better growth recorded when this prey is used as a food supplement. The interesting lipid profile of copepods and frozen flakes of sandeel (Ammodytes sp.) will equally yield interesting DHA values justifying the continuation of research on this topic (Okumura et al., 2005; F. Linares, personal communication).

Regarding tank design and other more appropriate physical conditions for rearing octopus paralarvae, no standardized model could be suggested, due to the fact that, as shown in Table 2, each team uses different volumes (from 25 to $9000 \mathrm{~L}$ ), colours (from black to white, moss green or grey), photoperiod ( 0,12 or $24 \mathrm{~h}$ ) or circulation systems (open, closed or semi-open). There is a general agreement on the fact that the main factor to be taken into account in selecting a proper culture tanks is that it allows homogeneous distribution of both paralarvae and prey in the water column. In order to achieve this aim, some authors (Iglesias et al., 2004; Okumura et al., 2005) use a gentle aeration at the bottom of the tank produced by diffuser stones, avoiding the formation of small bubbles that could get trapped inside the paralarvae mantle. Others use special water distribution and diffusion systems, such as a dripping water diffuser (Villanueva, 1995) or multiple superficial and tangential water inlets (Vidal et al., 2002), and even others (Carrasco et al., 2005, 2006) use a water inlet at the bottom of the tank, producing a vertical and upwards circulation, similar to that used for lobster culture. The combination of tank design and volume, aeration and position and flow of the water inlet can produce a large array of configurations and hydrodynamics to which paralarvae were exposed to during rearing. Therefore, future studies that evaluate the impact of the rearing environment on the survival of paralarvae are much needed.

Additionally, standardization of the feeding process (prey density, doses, etc.) is a shortcoming still to be solved in future research.

\section{Future research lines}

\subsection{Reproduction}

Although this phase is generally under control there are some aspects subject to improvement.

\subsubsection{Control of the sexual maturation}

To understand the effects of environmental stimuli that control maturation, more research is needed to obtain spawns in any season. This includes investigation on physical factors like temperature, photoperiod and salinity, as well as biotic factors like food availability, mating behaviour and the endocrine system.

\subsubsection{Genetic selection}

Genetic selection is needed to improve essential features of octopus culturing. This may include characteristics such as growth, maturation, and immune competence.

\subsubsection{Paralarval quality}

Research on the effects of broodstock conditions (size, nutrition, etc.) and environmental factors (temperature, light, etc.) are necessary to ensure the supply of large numbers of high quality paralarvae.

More defined criteria to determinate paralarval quality (related to biochemical composition, yolk content, hatching weight, etc.) need to be established.

\subsubsection{Pathology}

Investigation on pathology related to broodstock and egg masses is needed.

\subsection{Paralarval rearing}

\subsubsection{Feeding requirements}

Paralarval nutrition is a major source of variation. Research on nutritional requirements, prey acceptability and nutrient absorption should be carried out. This includes exploration of new live preys, biochemical composition of the diets, paralarval energetic demands, and development of formulated diets. The working group considered this area of research to be of the highest priority.

Other research lines to be considered are:

\subsubsection{Tank system and turbulence}

Research is needed to improve knowledge on the effects of system and tank design and fluid motion on paralarval survival and growth (e.g. the effects of tank design, water inlet, aeration, and water outlet on tank hydrodynamics). 


\subsubsection{Water quality}

Suitable water quality parameters should be determined to ensure optimal paralarval rearing and reduction of variability (e.g. factors like microbial population, use of probiotics, recirculation, open circuit system, gas supersaturation, and tolerance limits to, for example, metabolites like carbon dioxide and ammonia).

\subsubsection{Feeding environment}

Establishment of optimal feeding environment should be explored to ensure that paralarvae needs are satisfied (e.g. the effect of tank colour, turbidity, green water/clear water, light intensity and quality, photoperiod, prey density, prey size, and feeding schedule).

\subsubsection{Paralarval behaviour}

Paralarval responses to different biological and physical stimuli need to be mapped and quantified (e.g. predator-prey interactions, phototaxis, and chemotaxis).

\subsubsection{Paralarval development}

Research on aspects related to paralarval morphology, physiology, growth dynamics, and internal rhythms, needs to be carried out, aiming at understanding proper fitness of the paralarvae along the planktonic development.

\subsubsection{Pathology}

Identification of specific pathogens and bacterial growth in the rearing systems should be also taken into account.

\section{Conclusions}

It was concluded that the nutritional aspect is the most important factor of influence on paralarval mortality. Phospholipids, fatty acids and cholesterol among lipids; lysine, leucine and arginine, among amino acids, and copper among the essential elements, play a relevant role in the larval rearing process. It is believed that the PUFA content, especially DHA and EPA, constitutes one of the basic nutritional requirements.

The best results of paralarvae rearing have been achieved using diets of high PUFA level (Itami et al., 1963; Villanueva, 1995; Iglesias et al., 2002, 2004; Carrasco et al., 2003, 2005; Okumura et al., 2005); satisfactory results at around one month culture were also attained using Artemia enriched with Nannochloropsis sp.

However, in order to achieve conclusive results, live shrimp or selected crab zoeae seem to be the most appropriate prey to use as control.

More basic research is needed on nutritional requirements (lipids, proteins, essential elements, vitamins), physiology, behaviour and pathology. Furthermore, in order to enable for comparisons between research groups and to determine the success of the tested parameter it is essential to include survival and growth at initial benthic phase in future studies.

Zootechnical research is also needed on tank (type and design, colour, volume, etc.), water (quality, circulation, turbulence), and exploration of new live prey types (copepods, mysids, shrimps, etc.).

Finally, the working group members recognised the importance of a close coordination for further research between the different laboratories, and are committed to the internal exchange of information on new developments in order to maximize progress and minimise overlapping efforts.

\section{Acknowledgements}

This Working Group has been supported by the General Fisheries Secretariat (Spanish Ministry of Agriculture, Fishery and Food). Roger Villanueva was supported by the Centre de Referència de Recerca i Desenvolupament en Aqüicultura, CIRIT, Generalitat de Catalunya. Érica A. G. Vidal was supported by the Brazilian National Research Council (CNPq-PROFIX). We are also grateful for the participation and collaboration in the organization of the Working Group on paralarval rearing of $O$. vulgaris to Lisiane B. da Silva from FURG (Brazil), and Juan José Otero, María Jesús Lago and Covadonga Moxica from IEO (Vigo, Spain).

\section{References}

Aguado, F., García, B., 2002. Growth and food intake models in Octopus vulgaris Cuvier (1797): influence of body weight, temperature, sex and diet. Aquac. Int. 10, 361-377.

Bersano, J.G.F., 2003. Intensive cultivation of the calanoid copepod Acartia tonsa. A potential source of live food for aquaculture. Book of Abstracts. World Aquaculture, vol. 1. 95 pp.

Carrasco, J.F., Rodríguez, C., Rodríguez, M., 2003. Cultivo intensivo de paralarvas de pulpo (Octopus vulgaris, Cuvier) utilizando como base de la alimentación zoeas vivas de crustáceos. Libro de Resúmenes. IX Congreso Nacional de Acuicultura, Mayo 2003, Cádiz, Spain, pp. 255-256.

Carrasco, J.F., Rodríguez, C., Rodríguez, M., 2005. Cultivo intensivo de paralarvas de pulpo (Octopus vulgaris, Cuvier) utilizando como base de la alimentación zoeas vivas de crustáceos. Libro de Actas. IX Congreso Nacional de Acuicultura, Octubre 2005, Sevilla, Spain, pp. 219-222.

Carrasco, J.F., Arronte, J.C., Rodríguez, C., 2006. Paralarval rearing of the common octopus, Octopus vulgaris (Cuvier). Aquac. Res. 37, $1601-1605$.

Cerezo, J., García, B., 2003. Crecimiento y aprovechamiento nutritivo de dietas compuestas de distintos porcentajes de cangrejo y boga en el pulpo de roca (Octopus vulgaris Cuvier, 1797). Libro de resúmenes. IX Congreso Nacional de Acuicultura, Mayo 2003, Cádiz, Spain, pp. $248-250$. 
Dhont, J., Lavens, P., 1996. Tank production and use of ongrown Artemia. In: Sorgeloos, P., Lavens, P. (Eds.), Manual on the Production and Use of Live Food for Aquaculture. Fisheries Technical Paper, vol. 361. Food and Agriculture Organization of the United Nations, Rome, pp. 164-195.

Dhont, J., van Stappen, G., 2003. Biology, tank production and nutritional value of Artemia. In: Støttrup, J.G., McEvoy, L.A. (Eds.), Live Feeds in Marine Aquaculture, vol. 65-121. Blackwell Science Ltd. 318 pp.

Dhont, J., Lavens, P., Sorgeloos, P., 1991. Development of a lipid enrichment technique for Artemia juveniles produced in an intensive system for use in marine larviculture. In: Lavens, P., Sorgeloos, P., Jaspers, E., Ollevier, F. (Eds.), Larvi'91- Fish and Crustacean Larviculture Symposium. European Aquaculture Society, Special Publication, vol. 15. Ostend, Belgium, pp. 51-55.

Forsythe, J.W., Van Heukelem, W.F., 1987. Growth. In: Boyle, P.R. (Ed.), Cephalopod Life Cycles, vol. 2. Academic Press, London, pp. 351-365.

García, B., Aguado, F., 2002. Influence of diet on ongrowing and nutrient utilization in the common octopus (Octopus vulgaris). Aquaculture 211, 171-182.

García, J., Rodríguez, L.M., García, B., 2001. Estudio económico de una explotación tipo de engorde de pulpo (Octopus vulgaris) en Galicia, mediante la analítica de costes. IV Foro dos Recursos mariños e da Acuicultura das Rías Galegas, pp. 503-505.

García, B., Cerezo, J., Farazo, F., 2003a. Influencia del número de días de ayuno a la semana sobre el crecimiento y el índice de conversión en el pulpo de roca (Octopus vulgaris). IX Congreso Nacional de Acuicultura, 12-16 May, Cádiz, Spain.

García, J., Rodríguez, L.M., García, B., 2003b. Estudio económico de una explotación tipo de engorde de pulpo (Octopus vulgaris) en Galicia, mediante la analítica de costes. Actas IX Congreso Nacional de Acuicultura, May 2003, Cádiz, Spain, pp. 503-505.

Giménez, F.A., González, F.M.R., Nicolás, M.A.E., Llorente, M.D.H., Munuera, F.F., García, B.G., 1999. Efecto de la temperatura sobre la supervivencia en el transporte, estabulación y engorde de $O c$ topus vulgaris Cuvier (1797) en el Mediterráneo occidental. In: VII Congreso Nacional de Acuicultura, Las Palmas (Gran Canaria), 19-21 May 1999. Serie Monografías del ICCM Instituto Canario de Ciencias Marinas (ed.). n 4, pp. 174-179.

Globefish, 2006. http://www.globefish.org/index.php?id=3143. September 2006.

Hamazaki, H., Fukunaga, K., Yoshida, Y., Maruyama, K., 1991. Effects of marine microalgae Nannochloropsis sp. on survival and growth on rearing pelagic paralarvae of Octopus vulgaris, and results of mass culture in the tank of 20 metric tons. Saibai-giken 19, 75-84.

Hanlon, R.T., Messenger, J., 1996. Cephalopod Behaviour. University Press, Cambridge. 278 pp.

Henderson, R.J., Sargent, J.R., 1985. Fatty acid metabolism in fish. In: Cowey, C.B., Mackie, A.M., Bell, J.G. (Eds.), Nutrition and Feeding in Fish. Academic Press, London, pp. 349-364.

Iglesias, J., Sánchez, F.J., Otero, J.J., 1996. The octopus (Octopus vulgaris Cuvier): a candidate for aquaculture? International Council for the Exploration of the Sea. Council Meeting. ICES 1996/F:10. Mariculture Committee.

Iglesias, J., Sánchez, F.J., Otero, J.J., 1997. Primeras experiencias sobre el cultivo integral del pulpo (Octopus vulgaris Cuvier) en el I.E.O. In: Costa, J., Abellán, E., García, B., Ortega, A., Zamora, S. (Eds.), Actas del VI C. Nacional de Acuicultura. Cartagena 1997. ISBN: 84-491-0323-1, pp. 221-226.

Iglesias, J., Sánchez, F.J., Otero, J.J., Moxica, C., 2000. Culture of octopus (Octopus vulgaris, Cuvier). Present knowledge, problems and perspectives. Cah. Options Méditerr. 47, 313-321.
Iglesias, J., Otero, J.J., Moxica, C., Fuentes, L., Sánchez, F.J., 2002. Paralarvae culture of octopus (Octopus vulgaris Cuvier) using Artemia and crab zoeae and first data on juvenile growth up to eight months of age. Aquaculture Europe 2002. European Aquaculture Society. Special Publication, vol. 32, pp. 268-269.

Iglesias, J., Otero, J.J., Moxica, C., Fuentes, L., Sánchez, F.J., 2004. The completed life cycle of the octopus (Octopus vulgaris, Cuvier) under culture conditions: paralarval rearing using Artemia and zoeae, and first data on juvenile growth up to 8 months of age. Aquac. Int. 12, 481-487.

Iglesias, J., Fuentes, L., Sánchez, J., Otero, J.J., Moxica, C., Lago, M.J., 2006. First feeding of Octopus vulgaris Cuvier, 1797 paralarvae using Artemia: effect of prey size, prey density and feeding frequency. Aquaculture 261 (2), 817-822.

Imamura, S., 1990. Larval rearing of Octopus (Octopus vulgaris Cuvier). The progress of technological development and some problems remained. Collect. Breed 52, 339-343.

Itami, K., Izawa, Y., Maeda, S., Nakay, K., 1963. Notes on the laboratory culture of octopus larvae. Bull. Jpn. Soc. Sci. Fish. 29 (6), 514-520.

Lee, P.G., 1994. Nutrition of cephalopods: fuelling the system. Mar. Freshw. Behav. Physiol. 25 (1-3), 35-51.

Mangold, K., 1983. Octopus vulgaris. In: Boyle, P.R. (Ed.), Cephalopod Life Cycles, vol. I. Academic Press, London, pp. 335-364.

Mangold, K., Boletzky, S.V., 1973. New dates on reproductive biology and growth of Octopus vulgaris. Mar. Biol. 19, 7-12.

Moxica, C., Otero, J.J., Iglesias, J., Sánchez, F.J., 2001. Comportamiento reproductor, puestas y desarrollo embrionario del pulpo Octopus vulgaris en cautividad. Actas del VII Congreso Nacional de Acuicultura, Las Palmas, Mayo 1999.

Moxica, C., Linares, F., Otero, J.J., Iglesias, J., Sánchez, F.J., 2002. Cultivo intensivo de pararlarvas de pulpo, Octopus vulgaris Cuvier, 1797, en tanques de $9 \mathrm{~m}^{3}$. Bol. Inst. Esp. Oceanogr. 18 (1-4), 31-36.

Moxica, C., Fuentes, L., Hernández, J., Iglesias, J., Lago, M.J., Otero, J.J., Sánchez, F.J., 2006. Efecto de Nannochloropsis sp. en la supervivencia y crecimiento de paralarvas de pulpo Octopus vulgaris. IX Foro dos Recursos Mariños e da Acuicultura das Rías Galegas, October 2006, O Grove, Spain.

Muñoz, J.L., 2003. Engorde de pulpo (Octopus vulgaris Cuvier 1797) en condiciones naturales de un estero. Libro de Resúmenes del IX Congreso Nacional de Acuicultura, Cádiz, Spain, May 2003, pp. 264-266.

Naas, K.E., van der Meeren, T., Aksnes, D.L., 1991. Plankton succession and responses to manipulations in a marine basin for larval rearing. Mar. Ecol., Prog. Ser. 74, 161-173.

Navarro, J.C., Villanueva, R., 2000. Lipid and fatty acid composition of early stages of cephalopods: an approach to their lipid requirements. Aquaculture 183, 161-177.

Navarro, J.C., Villanueva, R., 2003. The fatty acid composition of $O c$ topus vulgaris paralarvae reared with live and inert food: deviation from their natural fatty acid profile. Aquaculture 219, 613-631.

Navarro, J.C., Amat, F., Sargent, J.R., 1992. Fatty acid composition of coastal and inland Artemia sp. populations from Spain. Aquaculture 102, 219-230.

Navarro, J.C., Amat, F., Sargent, J.R., 1993. The lipids of the cysts of freshwater- and marine-type Artemia. Aquaculture 109, 327-336.

O’Dor, R.K., Wells, M.J., 1987. Energy and nutrient flow. In: Boyle, P.R. (Ed.), Cephalopod Life Cycles, vol. 2. Academic Press, pp. 109-133.

Okumura, S., Kurihara, A., Iwamoto, A., Takeuchi, T., 2005. Improved survival and growth in Octopus vulgaris paralarvae by feeding large type Artemia and Pacific sandeel, Ammodytes personatus. Aquaculture 244, 144-157. 
Oltra, R., Roig, M., Alemany, F., Mezquita, F., 2005. Engorde de pulpo (Octopus vulgaris) en el Puerto de Denia (Alicante). In: Rey, M., et al. (Eds.), VII Foro do Recursos Mariños e da Acuicultura das Rías Galegas. Octubre 2004, O Grove, Spain, pp. 251-257.

Otero, J.J., Moxica, C., Sánchez, F.J., Iglesias, J., 2001. Engorde de pulpo (Octopus vulgaris Cuvier) a diferentes densidades de estabulación. Actas del VII Congreso Nacional de Acuicultura, Mayo 1999, Las Palmas.

Parra, G., Villanueva, R., Yúfera, M., 2000. Respiration rates in late eggs and early hatchlings of the common octopus, Octopus vulgaris. J. Mar. Biol. Assoc. U.K. 80, 557-558.

Portner, H.O., O’Dor, R.K., D.L., 1994. Physiology of cephalopod molluscs. In: Macmillan (Ed.), Lifestyle and Performance Adaptions. Gordon and Breach Publihers, Basel. 214 pp.

Rama-Villar, A., Faya-Angueira, V., Moxica, C., Rey-Méndez, M., 1997. Engorde de pulpo (Octopus vulgaris) en batea. In: Costa, J., Abellán, E., García, B., Ortega, A., Zamora, S. (Eds.), Actas del VI Congreso Nacional de Acuicultura, Cartagena, 1997. ISBN: 84491-0323-1, pp. 245-250.

Rasmussen, M.R., McLean, E., 2004. Comparison of two different methods for evaluating the hydrodynamic performance of an industrial-scale fish-rearing unit. Aquaculture 242, 397-416.

Rey-Méndez, M., Tuñón, E., Luaces-Canosa, M., 2003. Estudio de los efectos del peso inicial y el sexo sobre el comportamiento, la mortalidad y el crecimiento del pulpo (Octopus vulgaris, Cuvier 1797) en cultivo industrial. Libro de resúmens IX Congreso Nacional de Acuicultura (Mayo 2003, Cádiz, España), pp. 276-277.

Rodríguez, C., Carrasco, J.F., Rodríguez, M., 2003. Engorde de juveniles de pulpo (Octopus vulgaris, Cuvier 1797) en jaula. Libro de resúmenes IX Congreso Nacional de Acuicultura, Cádiz, Spain, May 2003, pp. 268-269.

Rodríguez, C., Carrasco, J.F., Arronte, J.C., Rodríguez, M., 2006. Common octopus (Octopus vulgaris Cuvier, 1797) juvenile ongrowing in floating cages. Aquaculture 254, 293-300.

Sánchez, F.J., Iglesias, J., Moxica, C., Otero, J.J., 1998. Growth of octopus (Octopus vulgaris) males and females under culture conditions. ICES CM 1998/M:47.

Sargent, J.R., McEvoy, L.A., Bell, J.G., 1997. Requirements, presentation and sources of polyunsaturated fatty acids in marine larval feeds. Aquaculture 155, 117-127.

Støttrup, J.G., McEvoy, L.A., 2003. Live Feeds in Marine Aquaculture. Blackwell Science, Oxford (UK). 318 pp.

Støttrup, J.G., Nosker, N.H., 1997. Production and use of copepods in marine fish larviculture. Aquaculture 155, 231-247.

Tuñón, E., Parada, A., Caeiro, C., Rey-Méndez, M., 2001. Estudio comparativo basado en la dieta diferenciada para el engorde de pulpo (Octopus vulgaris, Cuvier) en una explotación industrial. IV Foro dos Recursos Mariños e da Acuicultura das Rías Galegas, pp. 255-269.

van der Meeren, T., 1991. Production of marine fish fry in Norway. World Aquac. 22 (2), 37-40.

van der Meeren, T., 2003. Kartlegging av biokjemisk innhold i copepoder som basis for kvalitetsvurdering av fôr i oppdrett av marin fiskeyngel. Fisken og Havet, vol. 5. 39 pp. (in Norwegian with English abstract). http://www.imr.no/produkter/publikasjoner/ fisken_og_havet.

van der Meeren, T., Naas, K.E., 1997. Development of rearing techniques using large enclosed ecosystems in the mass production of marine fish fry. Reviews Fish. Sci. 5, 367-390.

van der Meeren, T., Fyhn, H.J., Pickova, J., Hamre, K., Olsen, R.E., Evjen, M.S., Lignell, M., 2001. Biochemical composition of copepods: seasonal variation in lagoon-reared zooplankton (Extended Abstract). In: Hendry, C.I., van Stappen, G., Wille, M., Sorgeloos, P. (Eds.), Larvi'01- Fish and crustacean larviculture symposium. Gent, Belgium, September 3-6. European Aquaculture Society, Special publication, vol. 30, pp. 614-615.

Vaz-Pires, P., Seixas, P., Barbosa, A., 2004. Aquaculture potential of the common octopus (Octopus vulgaris Cuvier, 1797): a review. Aquaculture 238 (1-4), 221-238.

Vidal, E.A.G., DiMarco, P.F., Wormuth, J.H., Lee, P.G., 2002. Optimizing rearing conditions of hatchling loliginid squid. Mar. Biol. 140, 117-127.

Vidal, E.A.G., Roberts, M., Martins, R.S., 2005. Yolk utilization, metabolism and growth in reared Loligo vulgaris reynaudii. Aquat. Living Resour. 18, 385-393.

Villanueva, R., 1994. Decapod crab zoeae as food for rearing cephalopod paralarvae. Aquaculture 128, 143-152.

Villanueva, R., 1995. Experimental rearing and growth of planktonic Octopus vulgaris from hatching to settlement. Can. J. Fish. Aquat. Sci. 52, 2639-2650.

Villanueva, R., Bustamante, P., 2006. Composition in essential and non-essential elements of early stages of cephalopods and dietary effects on the elemental profiles of Octopus vulgaris paralarvae. Aquaculture 261, 225-240.

Villanueva, R., Nozais, C., Boletzky, S.v., 1995. The planktonic life of octopuses. Nature 377, 107.

Villanueva, R., Nozais, C., Boletzky, S.v., 1996. Swimming behaviour and food searching in planktonic Octopus vulgaris Cuvier from hatching to settlement. J. Exp. Mar. Biol. Ecol. 208, 169-184.

Villanueva, R., Koueta, N., Riba, J., Boucaud-Camou, E., 2002. Growth and proteolytic activity of Octopus vulgaris paralarvae with different food rations during first-feeding, using Artemia nauplii and compound diets. Aquaculture 205, 269-286.

Villanueva, R., Riba, J., Ruíz-Capillas, C., González, A.V., Baeta, M., 2004. Amino acid composition of early stages of cephalopods and effect of amino acid dietary treatments on Octopus vulgaris paralarvae. Aquaculture 242, 455-478.

Watanabe, T., Katajima, C., Fujita, S., 1983. Nutritional value of live organisms used in Japan for mass propagation of fish: a review. Aquaculture 34, 115-143.

Wells, M.J., 1978. Octopus. Physiology and Behaviour of an Advanced Invertebrate. Chapman and Hall, London. 417 pp.

Wells, M.J., 1990. Oxygen extraction and jet propulsion in cephalopods. Can. J. Zool. 68, 815-824.

Young, R.E., Harman, R.F., 1988. 'Larva', 'paralarva' and 'subadult' in cephalopod terminology. Malacologia 29, 201-207. 